\title{
Factors Influencing Organic Food Purchase of Young Pakistani Consumers
}

\author{
* Dr. Ghulam Muhammad Mangnejo, Assistant Professor (Corresponding Author) \\ ** Dr. Urooj Talpur, Assistant Professor \\ *** Bakhtiar Ahmed Kuber, Assistant Professor
}

\begin{abstract}
This study has mainly focused on the various factors that influence the purchasing of organic food on young Pakistan consumers. This empirical examination has used the primary data that has been collected from various consumers. The revised "Theory of Reasoned Action" (TRA) Model has been successfully applied by this empirical research and the same had been applied by various empirical studies all over the world. It has been observed that environmentally friendly, nutrition, and food safety are the significant factors that influence consumers to purchase organic foods in Pakistan. Furthermore, this empirical examination has observed that most customers of organic food prefer fruits, vegetables, eggs, meat, milk, and beans. The unavailability, higher price, and the distrust of certification are the main hindrances in the growth of organic food in the economy. The study concludes and recommends the proper policy for the potential market of organic food at the national and international levels. This sector has much potential to create new job opportunities and to reduce unemployment in the economy.
\end{abstract}

Keywords: $\quad$ Organic food, Factors, Analysis, Young Pakistani Consumers

\section{Introduction}

The researchers have been investigating the relationship between diet and life-threatening diseases for the last few years all over the world (Southgate \& Ulbricht, 1991). Consumers have been made aware of unhealthy and healthy eating by these various empirical researches (Rees, Harden, \& Shepherd, 2006). As result, it has been observed that people are looking quite conscious about eating environment-friendly and healthy foods either in developing or developed countries. Further, most of the researchers are in the favour of the use of organic foods for better and healthy life because organic foods are beneficial for consumers and the environment (Santieerakul \& Ueasangkomsate, 2016; Shamsudin \& Basha, 2015). The precise and specific mechanism of production is being applied in the production of organic food that is economically, ecologically, and socially suitable. The production mechanism of organic foods is free from the use of chemical fertilizers, herbicides, growth hormones, synthetic pesticides, gene manipulation, and antibiotics (Haas, 2006). Hence, consumers have started to give preference the organic foods over inorganic foods. The purchasing concept of organic food merely existed in the advanced economies in the initial years. With time, the consumption and production of organic food are being spread all over the world. Particularly the markets of organic foods are being enormously increasing in developing countries, (Haroon Hafeez, Rafiul Haque, \& AlSwidi, 2014). Developing and developed countries have remarkably increased the production of organic foods. The production of organic foods in the global market has reached up to $\$ 18.6$ billion in 2015 (Lernoud, \& Willer, 2017). The production of organic foods is increasing in Asia. The four million hectares of land are under cultivation for the production of organic food in Asia. Pakistan, China, South Korea, Japan, and India have great potential and markets for organic foods. The rapid increase in demand and preference of people has made. The food industry of Pakistan has emerged as one of the largest earning industries due to rapid expansion in the demand and preference of people in the world market. The encouraging and suitable steps undertook by food policymakers have increased the trend of organic farming in the world, particularly in Asia, (Saeed, 2014). The National Institute of Organic Agriculture has installed the manufacturing plant for the production of organic pesticides, organic herbicides, and organic fertilizers in Islamabad. It has been estimated by PARC that around

* Shaikh Ayaz University, Shikarpur Email: mangnejogm81@ gmail.com

** University of Sindh, Jamshoro Email: talpur.urooj@yahoo.com

*** Shaikh Ayaz University, Shikarpur Email: bakhatiarkhuber@yahoo.com 
35,000 acres in 2005 to 150,000 acres in 2010 will be brought under the cultivation of organic foods in Pakistan. About 33\% of Pakistani farmers are producing organic foods and this number will be double in few years because of robust demand for organic foods at national and international markets (Ward \& Maloney, 1973). Zwolle has certified organic farms in Pakistan. Around 10,000 students and farmers have been trained for the production of organic foods by the network of organic agriculture in Pakistan. These trained students and farmers have been assigned to find out the new methods and techniques of production and educate others at the national level, Zani, B. et al, (2005). The organic food market is significantly expanding due to the awareness among the consumers, growers, and stakeholders in Pakistan. Pakistan is earning around $\$ 100$ million by exporting organic foods which are encouraging and a positive sign for higher production and new markets. This empirical study has been carried out in Pakistan. The quantitative method has been applied to gather the required data. The conceptual model and associated research hypothesis address the indirect and direct association between exogenous and endogenous variables i.e. organic food knowledge, attitude, product availability, culture, perceived expensiveness, subjective norms, and environmental concerns.

\section{Background}

It has been observed that the environmental and health effects of genetically modified organisms, nonnatural chemical, and pesticide products used in conventional agriculture have made people interested to buy organic foods, Wang and Teng, (2015). It is being believed by the customers that organic foods are healthier, sager, and nutritious, W and Teng, 2015. Customers are deriving a higher level of utility from organic foods, Rana and Paul, (2012). According to the Organic Trade Association, (2011), the market for organic foods has expanded enormously over the last few decades. It is believed that there is great potential in the organic industry. By considering it, this empirical research has been carried to investigate the factors that influence the consumption of organic foods by Pakistani consumers.

\section{Problem Formulation}

The economic and rapid population growth of the country has forced to depend on modern agricultural chemical products, Li and Ye, Wang, (2002). The heavy use of growth hormones, fertilizers, and pesticides has significantly improved the productivity of land in Pakistan. Higher productivity of land has caused considerable health, environmental issues and food safety problems all over the universe that paves the way for rapid demand for organic food, Chen and $\mathrm{Wu},(2008)$ and Li, (2006). Albeit the heavy use of fertilizers, antibiotics, growth hormones, and chemical pesticides have enormously enhanced the productivity of land in the country eventually that had caused various environmental issues and food safety problem in the economy, Dominique, (2007). With time, people are giving more attention to environmental issues and health problems. The stable and visible economic growth of various economies including Pakistan has paved the way for the higher purchase of organic foods in the local and world market, Chen, Wu, and Yin, (2008). The poor record of food safety in Pakistan is the viable reason for the huge demand for healthy food and a human-friendly environment. Some researchers have found a positive relationship between organic food purchases with age in western economies, Hughner et al. (2007); this shows the less intension of young consumers. Conversely, these young consumers looked more keen and conscious to purchase organic foods, Sjoden et al. (2003). In light of these empirical studies, the behavior and attitude gap are enormously huge in young consumers. The growth of organic foods and per-capita consumption in Denmark is enormously high in the world, Garmen and Mette, (2002). In Pakistan, the consumption of organic food is quite low. The purchase behavior, purchase intention, purchase attitudes and purchase barriers of young Pakistani consumers may be dissimilar Danish. So what are the attitudes of young Pakistani consumers? What is the ground reality in Pakistan? What are the barriers and motivations of organic food purchase? Most of the studies have focused on and examined the consumers in Western and Europe. While, in Pakistan, a very scanty amount of research has been carried out to explore the influential factors of organic food purchase among young Pakistani consumers.

\section{Research Question}

The research question has been formulated as under:

What are the key factors which can influence organic food purchase behavior among young Pakistani consumers?

How can firms design a successful marketing strategy for young Pakistani Consumers? 
The positive move in the demand for organic food in Pakistan is a sign of a promising future of the organic food market. As the young generation is the main power of future purchase of organic foods, so it is very important to examine the attitudes and perception towards organic food. This empirical examination aims to investigate the factors that influence young Pakistani consumers to purchase organic food in the country. This empirical study will provide valuable information and guidance to design successful marketing strategies.

\section{Literature Review}

The literature concerned with factors influencing organic food purchase has been presented as under. This empirical study has used the revised Theory of Reasoned Action (TRA) model as the basic theoretical framework. At first, the demographic profile of organic food consumers has been shown. Second, the key factors concerned with the revised TRA model that influence consumption and purchase of organic food have been emphasized. A third, the marketing implication has been explained from the 4Ps perspective (promotion, place, product, and price).

Yazhi Xin and Xiufeng, (2019) carried out an empirical examination of the factors that have an impact on the purchasing of organic foods in China by using primary data. This empirical study used the TRA model successfully and found the significant influence of certain factors on the purchase of organic food by young consumers in China. This empirical examination concluded that nutrition, food safety, and environmental friendly are the significant factors to influence the purchase of organic food in the country. Further, this empirical study found that the consumers like and give priority to purchase fruits, beans, vegetables, grains, meat, eggs, and milk to be organic that are ranked according to the degree of preference. The study suggested that the main barriers that bring about the gap between behavior and attitudes are the distribution of certifications and the price of organic food and unavailability. These findings have implications for marketing communications to consumers and potentially for organic product development.

\section{Profile of Organic Food Consumers}

One of the most significant aspects of consumer characteristics is consumer demographics. The demographic profiles of consumers .i.e. age, gender, income, and education level significantly impact their purchase intention of organic foods have been examined by previous studies, (Olmeda, Bernabeu \& Urena, 2008, Mattas, Zotos, \& Boutsouki, 2008, Bellows, Hallman \& Onyango, 2007, Worsley \& Lea, 2005). It has been observed by most of the studies that females are inclined to purchase organic food in comparison with male consumers. Vegetables and fruits are more frequently eaten by a female rather than male consumers. Further, it has been observed that female consumers are more healthconscious than male. They follow the given health recommendations by health experts in true sprit than male consumers, (Magnusson, 2004). On the other hand, some studies have observed the limited and minor influence of gender on the purchase of organic foods, (Mondelaers, 2009; Durham, 2007). Further, the significant role and impact of education on the purchase of organic food have been observed by some studies .i.e. (Urena, 2008; Zotos, 2006). Age has been found a significant variable for the consumption of organic foods, (Bugge et al, 1997). The old consumers pay more attention to their wealth, whereas young consumer pays more regards to their health and environment in China. So this has been observed and added in the existing literature regarding the decision of the consumption of organic foods by Pakistani consumer's especially young ones.

\section{Theoretical Framework}

The various studies have used the Theory of Reasoned Action (TRA) model to examine the behavior and attitude of consumers to purchase products, (Fishbein \& Ajzen, 1980). It has been suggested that consumers' attitude towards an object results from feeling and beliefs by the Fishbein Model. (Magnusson et al, 2003) has examined and found the positive influence of attitude and behavior towards the purchase of organic foods among Swedish consumers. In the light of the theory, the basis of the attitude on the available information regarding consumption of the product which can alter with newly provided information by various means. According to (Ward \& Briz, 2009), the consumption of organic foods can be increased with the support of more information about the benefits of organic foods. So firms and producers need to provide more information to the consumers of organic foods for higher and robust consumption of organic products.

Social norms bases on the normative beliefs and motivation to comply with other peoples' wishes, (Fishbein, 2000). Further, the motivation paves the way for people to behave according to the wishes of his/her family and friends. So if people are consuming organic foods that will influence others to 
purchase the same products. The critical relationship between consumer social norms and organic food was found by previous studies, (Chen, 2007).

\section{The Revised TRA Model}

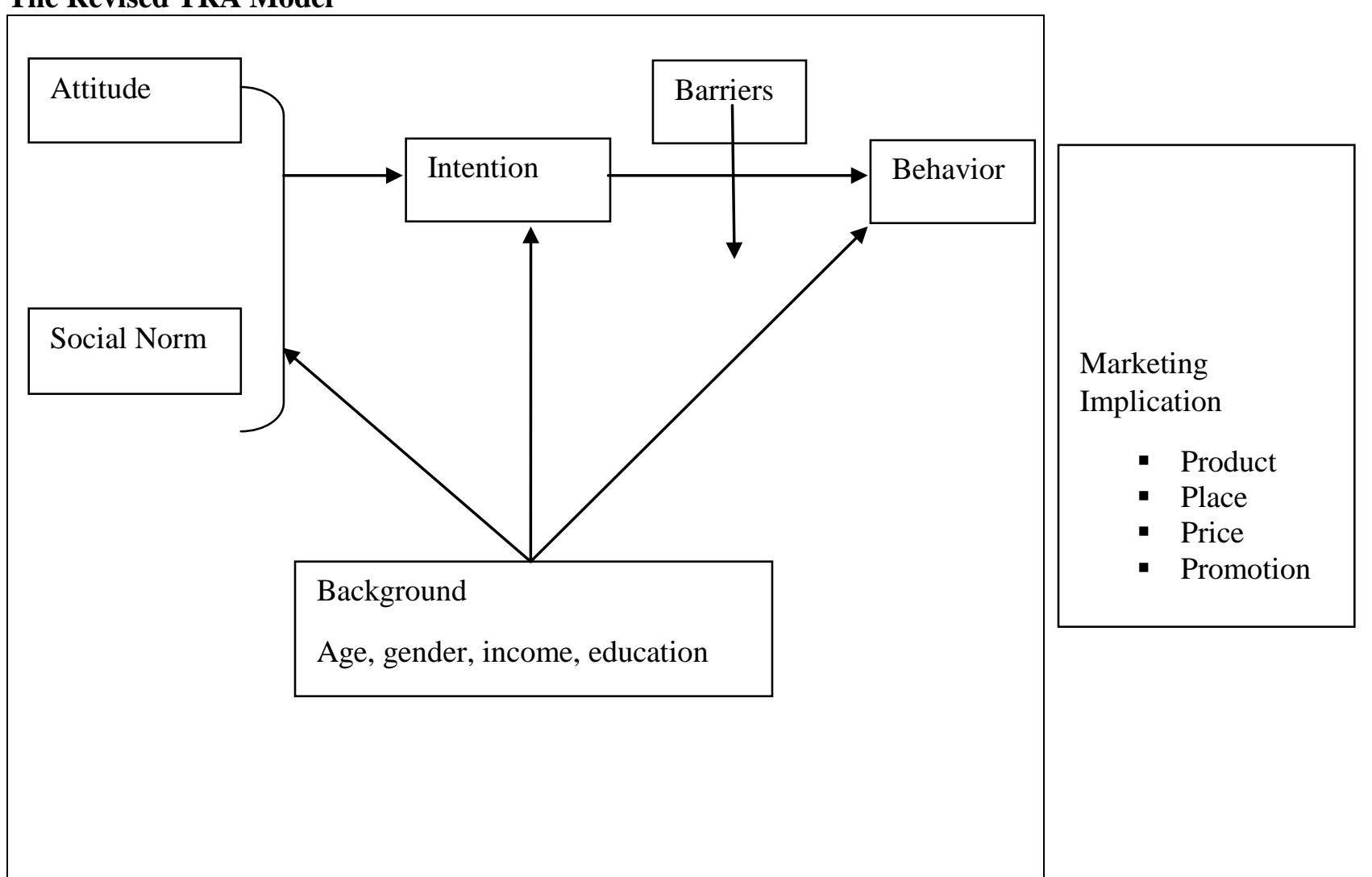

Source: Adopted from Fishbein and Ajzen, 1980, 1975 and Peter and Olson, 2010.

The questionnaire has been designed in the light of the model in the later part research methodology. The related factors i.e. social norms, attitude, barriers, consumer profile, purchase intention, and marketing implication have been depicted in the designed question. The study has tried to find out the key factors that can influence organic food purchase behavior among young Pakistani consumers by using the revised TRA Model. Further, this empirical study will be very handy and useful to guide and provide useful information for marketers and firms for successful and resultsoriented marketing strategies.

\section{Research Methodology}

The central and chief objective of this empirical study is to find out the key factors that influence the purchase of organic food among young Pakistani consumers. For the above-said purse, it is very essential to gather the required data .i.e. social norms, attitudes, barriers, and purchase behavior. For the provision of valuable information for marketers to expand the market, this empirical study has collected the required data about consumers. So the study surveyed to collect the big set of required data.

\section{Questionnaire}

The quantitative data on the factors that can influence organic food consumption among the young Pakistani consumers have been collected through a survey questionnaire. The research questionnaire contains 15 questions. This empirical examination has designed the questions in the survey based on the factors of the revised TRA Model, such as social norms, attitudes, socio-demographic characteristics, marketing implications, purchase behavior, purchase barriers, and purchase intention.

\section{Limitation of Study}

It is acknowledged that this empirical study has collected the data through a web-based sampling method which cannot be generalized to the whole population. Further, about $84 \%$ percent of the respondents fall between 20 to 25 years of age. The cultural reason can be another reason because most of the respondents were students and they don't earn income, thus they are lacking in purchasing experience. 


\section{Results and Analysis}

The following table depicts the demographic characteristics of respondents that include, age, gender, yearly income, number of children, and education level of households. It can be observed that the number of women respondents is higher than men and they are young between 20 to 25 years of age. The respondents' education level is much better at a higher level. Whereas the one-third of the respondents don't have any income and other respondents' salary is quite different from each other.

Table \# 01 Demographic characteristics of responds

\begin{tabular}{|c|c|c|c|c|}
\hline \multirow{2}{*}{ Gender } & Female & \multirow{2}{*}{\multicolumn{2}{|c|}{$\begin{array}{r}40 \% \\
60 \% \\
\end{array}$}} & \\
\hline & Male & & & \\
\hline \multirow{3}{*}{ Age } & $20-25$ & 256 & $82 \%$ & \\
\hline & $26-30$ & 44 & $15 \%$ & \\
\hline & $31-35$ & 09 & $3 \%$ & \\
\hline & No income & 97 & $31 \%$ & \\
\hline \multicolumn{2}{|c|}{ Yearly income $(\mathrm{PKR}) \leq 50000$} & 113 & $37 \%$ & \\
\hline & $50001-100000$ & 71 & $23 \%$ & \\
\hline \multirow{7}{*}{ Education level } & $100001-200000$ & 21 & $07 \%$ & \\
\hline & $\geq 200001$ & 07 & $02 \%$ & \\
\hline & Master or above & 74 & $24 \%$ & \\
\hline & Bachelor/Associate & 230 & $74 \%$ & \\
\hline & Secondary school, Technical & 03 & $01 \%$ & \\
\hline & Junior High School & 02 & $01 \%$ & \\
\hline & Primary School & 00 & $00 \%$ & \\
\hline
\end{tabular}

Source: Authors own surveyed and calculated

\section{Purchase Attitudes of Consumers}

It can be observed in our survey results that young Pakistani consumers have a significant position and inclination to purchase organic food. The motivational factors to purchase organic foods include animal welfare, safer, environmentally friendly, better flavor, and more nutrition.

Table \# 02, Motivations for organic food purchase in different genders

\begin{tabular}{|c|c|c|c|}
\hline & & Gender & Average Score \\
\hline \multirow{3}{*}{ Better flavor } & Female & 3.32 & \multirow{3}{*}{3.30} \\
\hline & & & \\
\hline & Male & 3.28 & \\
\hline \multirow{4}{*}{ More nutrition } & Female & 3.87 & \multirow{3}{*}{3.80} \\
\hline & & & \\
\hline & Male & 3.70 & \\
\hline & Female & 3.74 & \multirow{3}{*}{3.62} \\
\hline \multirow[t]{3}{*}{ Environmental friendly } & & & \\
\hline & Male & 3.43 & \\
\hline & Female & 3.61 & \multirow{3}{*}{3.52} \\
\hline \multirow[t]{3}{*}{ Animal welfare } & & & \\
\hline & Male & 3.38 & \\
\hline & Female & 4.21 & \multirow{3}{*}{4.14} \\
\hline \multirow[t]{2}{*}{ Safer, no fertilizer } & & & \\
\hline & Male & 4.02 & \\
\hline
\end{tabular}

Source: Authors own surveyed and calculated

It can be noticed from the above table that food safety is very important and motivation for young Pakistani consumers to purchase organic food. Sixty percent of respondents believe that organic food is being produced without the use of pesticides and fertilizers. Hence it is rich and healthy food for a better life and a better environment of the country. Further, it can be noticed in the above table that Pakistani women are more motivated by safety, better flavor, and more nutrition.

Table \# 03, Preference of familiar brands by different genders

\begin{tabular}{llcc}
\hline & Gender & \multicolumn{2}{c}{ Average percentage } \\
\hline \multirow{2}{*}{ Strongly agree and agree } & Female & $73.46 \%$ & $79.28 \%$ \\
& & & \\
& Male & $82.98 \%$ & 7 \\
\hline
\end{tabular}

Source: Authors own surveyed and calculated 
Table number three depicts the stronger preference of females for familiar brands than male consumers. Further, it can be noticed that young Pakistani consumers, particularly females have a big influence on the attitudes to purchasing organic food.

Table \# 04, the \% of organic food female and male would like to buy in each category

\begin{tabular}{|c|c|c|c|}
\hline & Gender & averag & \\
\hline \multirow{3}{*}{ Fruits } & Female & $81.11 \%$ & \multirow{3}{*}{$78.72 \%$} \\
\hline & & & \\
\hline & Male & $74.99 \%$ & \\
\hline \multirow{3}{*}{ Vegetables } & Female & $80.06 \%$ & \multirow{3}{*}{$78.07 \%$} \\
\hline & & & \\
\hline & Male & $75.01 \%$ & \\
\hline \multirow{3}{*}{ Eggs } & Female & $69.68 \%$ & \multirow{3}{*}{$67.72 \%$} \\
\hline & & & \\
\hline & Male & $64.67 \%$ & \\
\hline \multirow{3}{*}{ Milk } & Female & $72.48 \%$ & \multirow{3}{*}{$70.31 \%$} \\
\hline & & & \\
\hline & Male & $66.94 \%$ & \\
\hline \multirow{3}{*}{ Tea and Coffee } & Female & $56.91 \%$ & \multirow{3}{*}{$58.82 \%$} \\
\hline & & & \\
\hline & Male & $6179 \%$ & \\
\hline \multirow{3}{*}{ Grains and Beans } & Female & $72.07 \%$ & \multirow{3}{*}{$70.48 \%$} \\
\hline & & & \\
\hline & Male & $67.98 \%$ & \\
\hline \multirow{3}{*}{ Meat } & Female & $67.15 \%$ & \multirow{3}{*}{$78.07 \%$} \\
\hline & & & \\
\hline & Male & $70.25 \%$ & \\
\hline
\end{tabular}

Source: Authors own surveyed and calculated

Table number four depicts the percentage of organic food that young Pakistani females and males are intended to purchase in the economy. In this empirical analysis, it can be observed that females are more intended to purchase more organic, fruits, vegetables, grain, beans, and eggs.

The attitude part concludes and suggests that young Pakistani consumers keep a very positive and significant attitude towards the purchasing of organic foods in the country. Particularly people are willing to purchase more vegetables and fruits.

\section{Social Norms}

It has been observed in this empirical study that friends' and family members' advice has a significant influence on the decision to purchase organic foods, most of the respondents strongly agree or agree in our survey. Further, it has been examined that a very minor number of people disagree or strongly disagree to influence friends and family members to purchase organic food. The statistic of our survey depicts the higher percentage of about $75 \%$ of the female with compared to $67 \%$ male are strongly agree with advice from friends and family members to purchase organic foods.

\section{Results Discussion}

It has been seen and observed in our survey results that young Pakistani consumers keep great intentions and positive significant intentions to buy organic foods in our economy. The significant reason to buy organic food is safety among young consumers. The use of conventional foods has resulted in various health problems and diseases in various economies, Gore, (2008). The rapid increase in cancer patients in recent years has witnessed in the country, in resulting most patients are losing their lives. And this can be the main reason for people to choose and buy organic foods in the country.

\section{Barriers}

It has been examined and observed that there are a significant intention and behavior gap among the young Pakistani consumers of organic foods. This considerable gap has been resulted due to the high availability and prices of organic foods, Aagaard et al, (2014). This empirical study has found another barrier that most people lack in trust that the food they are buying either is organic or conventional. The distrust among the young Pakistani consumers about organic food certification is very common. This mistrust has a large negative impact on consumers' purchase behavior in the economy, Angulo et al. (2005). So the government and marketers should design and chart out the policy to develop the trust of the consumer for expansion of the organic food market at the local and international level. 


\section{Implications for Firms}

In light of consumer investigation of the consumption of organic food among Pakistani consumers, there are some significant suggestions for the expansion of the organic food market.

\section{Product}

As it is christened clear that people purchase either conventional or organic food from the market for deriving the utility. Therefore it is very imperative to elucidate the difference between organic and conventional food to the purchasers. The fresh color, informative label, and attractive packing are the significant indications of organic food. Sometimes it has been observed that even the fresh organic food is unappealing, so it is very important for the firms to highlight the natural way they are grown. According to Gore, (2008), the consumption of organic would be a better choice since organic foods are grown naturally. The numerous empirical examinations have found that organic crops generally contain more iron, vitamin c, phosphorus, and magnesium. Further organic crops contain significantly fewer nitrates than conventional crops. So the consumer can be attracted by the nutrition ingredients of organic food and generate affirmative attitudes. It is much better and striking to make available translucent information regarding the whole procedure of production of organic food. Hence customers can rely upon certification/ brands that product is an organic one.

\section{Price}

The results of this empirical examination confirm that the price of organic food is the key barrier to enhance the demand for organic food in the country. Price of the product can also be used to position a product as a good value for money. According to Olson and Peter, (2010), if the product is perceived to be of greater value by the people, they are likely ready to pay more price. So the producer must educate their customers about the reason to charge a premium price. Since the cost of production of organic food is quite higher than conventional food, because the animals that are used to produce organic food are not given antibiotics and they should have access to fresh water, outdoors, pasture, and air (Gore, 2008).

\section{Place}

The handsome number of outlets and good site locations has significant importance in the food market, Olson and Peter, (2010). Organic food should be easily available for consumers to be purchased. If the organic foods are made available in retail outlets .i.e. supermarkets then it will create the choice for customers either to purchase organic or conventional products. The different supplier's i.e. health food shops and supermarkets can easily attract and sell organic food to potential customers. Further, the buyers' requirements and needs must be significantly considered and weighted for the smooth expansion of the market.

\section{Promotion}

According to Olson and Peter, (2010), a favorable image can be created through advertisement. The promotion and advertisement can easily inform customers about the possessed attributes of the organic product and how the characteristics differentiate organic food from conventional food. The test of organic food can be expressed by a few consumers. Further, it is the responsibility of marketers to teach consumers about the particular less-risk and more benefits of the consumption of organic products. By using the various channels the knowledge and positive attitudes of consumers towards organic food can be promoted through television, store ads, magazines, websites, and newspapers. This empirical study has observed that consumers have shown significant intention to buy organic products with familiar brands.

\section{Conclusion}

The major and central object of this empirical study is to examine the key and essential factors that can impact the organic food purchase manners of young Pakistani consumers. The questionnaire of the study has principally focused on purchasers' social norms, attitudes, purchase barriers, purchase behavior, and marketing of organic foods. The positive and significant attitudes towards organic food have been found in young Pakistani consumers. This empirical study suggests enhancing the knowledge of consumers of organic foods. Consumers must be educated about the reasons for charging a premium price by marketers. The organic food stores, vegetable markets, and supermarkets are the significant equipment and places to enhance the supply and consumption of organic foods. The internet also can be very handy to sell organic foods.

Organic foods have a great future and market in Pakistan because the young generation of the country is paying more attention to a better environment, quality of life, and health. The consumers' 
purchasing power improves with positive economic growth and development. If the government and producers pay required attention to the production and consumption of organic food, it will create more job opportunities and the country can earn valuable foreign reserves. This will support in reducing the trade deficit and promote the balance of trade and balance of payments. When the economy earns a handsome amount of foreign reserves this appreciates its currency value. In nutshell, organic products have a promising future in Pakistan and all over the world.

\section{References}

Ajzen, I. \& Fishbein, M. 2000, "Attitudes and the Attitude-Behavior Relation:

Ajzen, I. 1991, "The theory of planned behavior", Organizational Behavior and

Human Decision Processes, Vol. 50 No. 2, pp. 179-211.

Ajzen, I. \& Fishbein, M. 1975. Belief, Attitude, Intention and Behavior: An Introduction to Theory and Research, Addison-Wesley Publishing Co., Reading MA.

Ajzen, I. \& Fishbein, M. 1980. Understanding Attitudes and Predicting Social Behavior, PrenticeHall, Englewood Cliffs, HJ.

Angulo, A.M., Gil, J.M. and Tamburo, L. 2005, "Food safety and consumers' willingness to pay for labeled beef in Spain", Journal of Food Products Marketing, Vol. 11 No. 3, pp. 89-105.

Aschemann-Witzel, J. \& Niebuhr Aagaard, E.M. 2014, "Elaborating on the attitude-behavior gap regarding organic products: young Danish consumers and in-store food choice", International Journal of Consumer Studies, vol. 38, no. 5, pp. 550-558.

Chen, M.F. 2007, "Consumer attitudes and purchase intention about organic foods in Taiwan: moderating effects of food-related personality traits", Food Quality and Preference, Vol. 18 No. 7, pp. 1008-1021.

Teng, C. \& Wang, Y. 2015, "Decisional factors driving organic food consumption", British Food Journal, vol. 117, no. 3, pp. 1066-1081.

Davies, A., Titterington, A.J. \& Cochrane, C. 1995, "Who buys organic food: A profile of the purchasers of organic food in Northern Ireland", British Food Journal, vol. 97, no. 10, pp. 1723.

Gore, S. 2008, "What You Should Know about Organic Foods", Journal of Renal Nutrition, vol. 18, no. 4, pp. e13-e15.

Giannini, B., Chen, S., Paramonov, P. \& Wu, Y.Y. 2014, "Purchase likelihood prediction for targeted organic food marketing campaigns in China", PICMET, pp. 1759.

Grankvist, G. \& Biel, A. 2002. Activating environment as purchase criteria: A switch to eco-labeled food products. In G. Grankvist, Determinants of choice of eco-labeled products. Doctoral dissertation, Göteborg University, Göteborg, Sweden, ISBN 91-628-5411-9.

Hoefkens, C., Campo, J. V., Verbeke, W., Aertsens, J., \& Mondelaers, K. 2009, "The nutritional and toxicological value of organic vegetables: Consumer perception versus scientific evidence", British Food Journal, 111(10), 1062-1077.

Kotler, P., \& Armstrong, G. 2010, Principles of marketing. Pearson Education.

Krystallis, A., Vassallo, M., Chryssohoidis, G. \& Perrea, T. 2008, "Societal and individualistic drivers as predictors of organic purchasing revealed through a portrait value questionnaire (PVQ)based inventory", Journal of consumer behavior, vol. 7, no. 2, pp. 164-187.

Krystallis, A., Fotopoulos, C., \& Zotos, Y. 2006, "Organic Consumers' Profile and Their Willingness to Pay (WTP) for Selected Organic Food Products in Greece", Journal of International Consumer Marketing, vol. 19, no. 1, pp. 81-106.

Lea, E. \& Worsley, T. 2005, "Australians' organic food beliefs, demographics and values", British Food Journal, vol. 107, no. 11, pp. 855-869.

Lockie, S., Lyons, K., Lawrence, G. \& Mummery, K. 2002, "Eating 'Green': Motivations behind organic food consumption in Australia", Sociologia Ruralis, vol. 42, no. 1, pp. 23-40.

Magnusson, M. 2004, Consumer Perception of Organic and Genetically Modified Foods: Health and Environmental Considerations, Uppsala: Acta Universitatis Upsaliensis.

Magnusson, M.K., Arvola, A., Hursti, U.K., Åberg, L. \& Sjödén, P. 2003, "Choice of organic foods is related to perceived consequences for human health and environmentally friendly behavior", Appetite, vol. 40, no. 2, pp. 109-117.

Nasir, V.A. \& Karakaya, F. 2014; 2013, "Underlying motivations of organic food purchase intentions", Agribusiness, vol. 30, no. 3, pp. 290-308. 
Organic Trade Association. 2011. Industry statistics and projected growth. Washington, DC Retrieved March 22, 2015, from http://www. ota.com/organic/mt/business.

Padel, S. and Foster, C. 2005, "Exploring the gap between attitudes and behavior understanding why consumers buy or do not buy organic food", British Food Journal, Vol. 107 No. 8, pp. 606625 .

Pearson, D. \& Henryks, J. 2008, "Marketing organic products: exploring some of the pervasive issues", Journal of Food Products Marketing, vol. 14, no. 4, pp. 95-108.

Peter, J.P. \& Olson, J.C. 2010, Consumer behavior \& marketing strategy, McGraw-Hill Higher Education, Boston.

Sunderer, G. \& Rössel, J. 2012, "Morality or economic interest? The impact of moral motives and economic factors on the purchase of fair trade groceries", International Journal of consumer studies, vol. 36, no. 2, pp. 244-250.

Saunders, M., Lewis, P. \& Thornhill, A. 2012, Research Methods for Business Students, s.n., S.1.

The Economist, 2013. "Thought for food". Retrieved May 15, 2015, from http://www.economist.com/ blogs/graphicdetail/2013/03/daily-chart-5.

Thompson, G.D. 1998, "Consumer demand for organic foods: what we know and what we need to know", American Journal of Agricultural Economics, vol. 80, no. 5, pp. 1113-1118.

Tsakiridou, E., Boutsouki, C., Zotos, Y. \& Mattas, K. 2008, "Attitudes and behavior towards organic products: an exploratory study", International Journal of Retail \& Distribution Management, vol. 36, no. 2, pp. 158-175.

Ureña, F., Bernabéu, R. \& Olmeda, M. 2008, "Women, men, and organic food: differences in their attitudes and willingness to pay; a Spanish case study", International Journal of consumer studies, vol. 32, no. 1, pp. 18-26.

Wandel, M. \& Bugge, A. 1997, "Environmental concern in consumer evaluation of food quality", Food Quality and Preference, vol. 8, no. 1, pp. 19-26.

Ye, X.J., Wang, Z.Q. and Li, Q.S. 2002, "The ecological agriculture movement in modern China”, Agriculture, Ecosystems and Environment, Vol. 92 No 2-3, pp. 261-281.

Yin, S.J., Wu, L.M. and Chen, M. 2008, "Demand analysis for organic food based on the consuming willingness", Agricultural Technology and Economy, No. 5, pp. 81-88.

Zakowska-Biemans, S. 2011, "Polish consumer food choices and beliefs about organic food", British Food Journal, Vol. 113 No. 1. 